\title{
A Rare Case of Amatoxin Poisoning in the State of Texas
}

\author{
Wei-Chung Chen ${ }^{\mathrm{a}} \quad$ Mahwash Kassi $^{\mathrm{a}} \quad$ Umair Saeed $^{\mathrm{a}}$ \\ Catherine T. Frenette ${ }^{\mathrm{b}}$ \\ ${ }^{a}$ Department of Medicine and ${ }^{b}$ Division of Gastroenterology and Hepatology, \\ The Methodist Hospital, Weill Cornell Medical College, Houston, Tex., USA
}

\section{Key Words}

Amatoxin poisoning $\cdot$ Texas $\cdot$ Amanita $\cdot$ Acute liver injury $\cdot$ Mushroom ingestion · Mycetismus

\begin{abstract}
Ingestion of mushrooms from the genus Amanita can present detrimental consequences to the human body. The mushroom is frequently found in the coastal Pacific Northwest, Pennsylvania, New Jersey, and Ohio. Amanitin, one of the two distinct toxins isolated from the Amanita mushroom, is responsible for the majority of symptoms and signs seen with mushroom poisoning. Clinically, ingestion of these mushrooms can result in a wide range of clinical symptoms including nausea, vomiting, crampy abdominal pain, and diarrhea. There have been several case reports of patients who developed severe hepatic failure that required liver transplantation. Thus, it is important to recognize the symptoms early and treat the patients with the available agents including multidose activated charcoal, $\mathrm{N}$-acetylcysteine, penicillin $\mathrm{G}$, and Silybum. Through an extensive literature search, we found no published literature on amatoxin poisoning in the state of Texas. With new cases of amatoxin poisoning emerging in the state, it is important for healthcare providers and workers to have a better awareness and early recognition of the detrimental effects of Amanita species poisoning and to be educated to provide the proper care for this group of patients.
\end{abstract}

\section{Introduction}

There are over 5,000 species of mushrooms and approximately 52 species are poisonous to humans [1]. Amanita mushroom plays a major role in mycetismus and has been reported in case reports of different states in the United States. Some features that are used to identify Amanita species include: cream-colored gills, yellowish-brown cap, and solid stalk with round base [2]. Amanita species are frequently found in the coastal Pacific Northwest, Pennsylvania, New Jersey, and Ohio. They tend to grow in oak 
woodlands or in lawns next to oak trees [1,2]. This is corroborated by case reports dating back to the 1970s (table 1). Specifically, the majority of cases are located in the Northwest/Oregon and California area. There are approximately 200 species of wild mushrooms in the state of Texas, but no formal report of amatoxin poisoning has been noted in the recent literature [3].

Amatoxins are found within the fungal families Amanitaceae (genus Amanita), Agaricaceae (genus Lepiota), and Cortinariaceae (genus Galerina). Amanita species that contain amatoxins include: Amanita phalloides, A. virosa, A. verna, A. ocreata, A. bisporigera, A. suballiacea, A. tenufolia, and A. hygroscopica [4]. Among the Amanita species mushrooms, $A$. phalloides has the highest toxin content and is the most poisonous Amanita species. Compared to Amanita species, Galerina and Lepiota species mushroom have less toxin content and contribute to less detrimental health consequences in humans [4]. Different amatoxins are isolated and the main toxins isolated include alpha-, beta- and gamma-amanitins. The principal amatoxin that causes the majority of morbidity and mortality in the ingestion of Amanita mushroom is alpha-amanitin [5]. The toxin is absorbed across the intestine, and $60 \%$ of the absorbed toxin is excreted into the bile and undergoes enterohepatic circulation [6]. Unlike other poisonous mushrooms, amatoxin has a prolonged enterohepatic circulation, thus making it an important potential cause of acute liver failure. After the toxin returns to the liver and is absorbed by the hepatocytes, it inhibits RNA polymerase II and interrupts mRNA synthesis of vital structural proteins, leading to cellular necrosis [1].

Mycetismus or mushroom poisoning especially from Amanita mushrooms can be life-threatening. The major consequences from ingestion of these mushrooms can result in hepatic failure that leads to coagulopathy, encephalopathy, hepatorenal syndrome, and death [1]. Despite major health consequences from amatoxin mushroom poisoning, there is little literature that report amatoxin poisoning in the state of Texas. In this case report, we present a case of mycetismus from Amanita mushrooms near the Houston area and we also briefly discuss the pathophysiology, clinical presentation, and treatment options related to mushroom toxicity.

\section{Case Report}

A 64-year-old Chinese female presented with a 1-day history of nausea and vomiting. She vomited at home 10-12 times, and the vomit was clear-looking, with no blood. She also had 6-8 episodes of watery non-bloody diarrhea. The patient had associated abdominal pain mostly in the lower abdomen, and it was crampy in nature associated with bowel movements. For her initial symptoms, she was evaluated at a local emergency room and the final working diagnosis was gastroenteritis. She was discharged on ciprofloxacin and loperamide. However, her symptoms failed to improve and she was brought to The Methodist Hospital. The patient had a past medical history of hypertension and took Chinese herbal medications for hypertension. On presentation, she had a maximum temperature of $97^{\circ} \mathrm{F}$, a heart rate of 82 , a blood pressure of $140 / 70$ on sitting and 135/70 on standing, a respiratory rate of 16 , and an oxygen saturation of $97 \%$. Her physical exam was overall benign. Her initial lab showed WBC 13.5, ALT 231, AST 375, PT 15.7, INR 1.3, and negative hepatitis serologies. She also underwent an abdominal ultrasound that was within normal limits. Upon further understanding of the patient's history, it was found that she and her husband had picked up wild mushrooms from the sidewalk around the Houston area and cooked the mushrooms for lunch and dinner. The patient was admitted for elevation of liver enzymes and continued symptoms of nausea and vomiting. Initially, she was started on $\mathrm{N}$-acetylcysteine, and the poison control center was contacted for further assistance in the patient's care. With the assistance of the poison control personnel, they were able to identify the mushroom from the Amanita species. Since admission, the 
patient began to have increasing levels of her liver enzymes and at one point, her ALT was 1,227 and AST was 1,378 ( $\underline{\text { fig. } 1}$ ). Her prothrombin and INR levels were also elevated during the hospital course (fig. 2). Due to acute liver injury, she was transferred to the medical intensive care unit for observation and higher level of care. The husband was also admitted and had similar symptoms but only mild elevations in liver enzymes that only required supportive care throughout hospitalization. The hepatology service was consulted for the acute liver injury and penicillin $G$ was added as part of the treatment. Since starting pencillin G, the patient's liver function test continued to improve. She was transferred to the hospital floor on hospital day 2 and discharged the following day.

\section{Discussion}

Amanita poisoning occurs in three separate stages [1, 5, 7]. The first stage or incubation stage usually occurs from 6 to $12 \mathrm{~h}$ after ingestion and patients usually do not present any symptoms during this time. During the second stage or gastrointestinal stage, which takes place 6-16 h after ingestion, patients develop abdominal pain, nausea, vomiting, and diarrhea for up to $24 \mathrm{~h}$. During the final stage or cytotoxic stage, between 24-48 $\mathrm{h}$ after ingestion of the mushroom, sign and symptoms of liver damage begin to develop. During this phase, patients are free of gastrointestinal symptoms, but they can present with jaundice and hemorrhage. There are also elevations in liver tests, prothrombin time, and ammonia levels. Patients can develop hepatic encephalopathy, profound coagulopathy, and renal failure secondary to hepatorenal syndrome. During the cytotoxic stage, the prolonged enterohepatic recirculation further recycles the amatoxin through the liver multiple times. Specifically, it is excreted into the bile duct and reabsorbed through the ileum and back into the portal circulation. The recirculation of toxin inside the body further prolongs liver damage and progresses from liver injury to liver failure. In severe cases, patients may require liver transplantation for survival.

There are different options available for treating amatoxin poisoning. Multidose activated charcoal is commonly used because the toxin has a high affinity to charcoal and this helps to reduce the absorption of the toxin through the intestine [8]. Another agent that is commonly used in practice is penicillin $G$ and works well in many settings. It competes with amatoxin for binding sites on serum proteins and prevents hepatocyte uptake [9]. Pencillin $\mathrm{G}$ also helps to prevent the progression of hepatic encephalopathy. In one study, the suggested dose for penicillin $\mathrm{G}$ is $40,000,000 \mathrm{U} /$ day for adults and $1,000,000 \mathrm{U} /$ day for children [10]. Another beta-lactam antibiotic used in the setting of amatoxin poisoning is ceftazidime and it has been shown to be more effective in some studies than penicillin G. It is usually administered $4.5 \mathrm{~g}$ i.v. every $2 \mathrm{~h}$ [10]. Silybum marianum, a silymarin complex, is a flavonolignan isolated from milk thistle and inhibits binding of alpha-amanitin to hepatocytes [5]. It also competes with amatoxin for transmembrane transport. One of the major compounds isolated from silymarin is silybin. Silybin dihemisuccinate is usually administered at an initial dose of $5 \mathrm{mg} / \mathrm{kg}$ by i.v. infusion over $1 \mathrm{~h}$, followed by $20 \mathrm{mg} / \mathrm{kg} /$ day by continuous i.v. infusion for 6 days until the liver enzymes have normalized [10]. Currently, silymarin is only incorporated in food supplements and is not yet approved by the FDA as a treatment for amatoxin poisoning. It is not available in the United States. Studies have suggested that thioctic acid provides a therapeutic effect on amatoxin hepatotoxicity. The chemical serves as a free radical scavenger and prevents lipid peroxidation of cell membrane. In the clinical setting, it is administered with glucose at doses of $300 \mathrm{mg} / \mathrm{kg} /$ day in four divided doses 
and then $600 \mathrm{mg} / \mathrm{kg} /$ day and $50-150 \mathrm{mg} / \mathrm{kg} /$ day [10]. Cimetidine, a cytochrome P450 inhibitor, is an antioxidant agent used in the treatment of amatoxin poisoning. It is usually given along with penicillin $\mathrm{G}$ at a dose of $300 \mathrm{mg}$ i.v. administered every $8 \mathrm{~h}$ [10]. N-acetylcysteine (NAC, Mucomyst) supplies sulfhydryl groups to act as a substrate for detoxifying reactive toxic intermediates $[1,5]$. Vitamin $C$ is also used to treat this group of patients and it inhibits lipid peroxidation and is used as a hepatocyte protector [9]. Liver transplantation is reserved for patients with encephalopathy and severe liver decompensation.

Despite many reported cases of amatoxin poisoning in other states of the United States, amatoxin poisoning has not been formally reported in Texas. According to Barbee et al. [3], the most common mushroom exposure in the state of Texas is Psilocybin, but little is known about the prevalence of Amanita exposure in the state of Texas. With new cases located in the state of Texas, it is increasingly important to recognize the deleterious effects of amatoxin poisoning and to be able to address the illness once the diagnosis is made. Further advances in the quality of care are necessary to better locate areas with growth of Amanita species and to provide adequate warning for travelers not to ingest the mushroom. Increasing collaboration with poison control centers is warranted to better diagnose and treat patients with potential amatoxin or other mushroom poisoning. Furthermore, with mushroom poisoning becoming more prevalent in the state of Texas, it is also important to educate health care providers and workers about early recognition of potential ingestion and medical disease management.

\section{Conclusion}

We have presented a case of Amanita poisoning in the state of Texas and with new cases emerging in the state of Texas, health care providers need to be have better awareness of the serious consequences of mycetismus from Amanita mushrooms and to provide a proper management plan for these patients.

\section{Disclosure Statement}

The authors have no funding or conflicts of interest to disclose. 
Table 1. Literature review of reported Amanita poisoning in the last 30 years in the United States

\begin{tabular}{|c|c|c|c|}
\hline First author & Journal, year & Clinical presentation & Region \\
\hline French [9] & Clin Toxicol, 2011 & $\begin{array}{l}3 \text { cases of Amanita phalloides mushroom poisoning in the } \\
\text { Pacific Northwest of the US }\end{array}$ & Oregon \\
\hline Cress [2] & Clin Gastroenterol Hepatol, 2011 & $\begin{array}{l}1 \text { case of Amanita phalloides toxicity that resulted in } \\
\text { fulminant hepatic failure and required orthotopic liver } \\
\text { transplantation }\end{array}$ & Delaware \\
\hline West [11] & J Med Toxicol, 2009 & $\begin{array}{l}1 \text { case report with delayed renal failure; renal failure } \\
\text { predominant manifestation }\end{array}$ & $\begin{array}{l}\text { Oregon/ } \\
\text { Pacific Northwest }\end{array}$ \\
\hline Madhok [5] & Minn Med, 2007 & $\begin{array}{l}7 \text { Minnesota residents who developed symptoms of Amanita } \\
\text { poisoning after consuming cooked mushrooms picked at a } \\
\text { county park }\end{array}$ & Minnesota \\
\hline Madhok [6] & Pediatr Emerg Care, 2006 & 3 cases of exposure to Amanita bisporigera & Missouri \\
\hline Broussard [1] & Am J Gastroenterol, 2001 & $\begin{array}{l}4 \text { cases of Amanita virosa ingestion with clinical presentation } \\
\text { from complete recovery to fulminant hepatic failure }\end{array}$ & Ohio \\
\hline Pomerance [12] & J Pediatr, 2000 & $\begin{array}{l}\text { a } 15 \text {-year-old boy with fulminant hepatic failure after } \\
\text { drinking mushroom tea (containing Amanita phalloides) } \\
4 \text { days before admission }\end{array}$ & Florida \\
\hline Mullins [13] & Vet Hum Toxicol, 2000 & $\begin{array}{l}2 \text { cases of confirmed Amanita phalloides poisoning } \\
\text { treated with hemodialysis or hemoperfusion and neither } \\
\text { contributed to the clearance of amatoxin }\end{array}$ & Oregon \\
\hline Yamada [14] & West J Med, 1998 & 10 case reports of amatoxin poisoning in Northern California & California \\
\hline Warden [7] & Acad Emerg Med, 1998 & $\begin{array}{l}4 \text { cases of Amanita smithiana ingestion that led to acute renal } \\
\text { failure }\end{array}$ & $\begin{array}{l}\text { Oregon/ } \\
\text { Pacific Northwest }\end{array}$ \\
\hline $\mathrm{CDC}[15]$ & $\begin{array}{l}\text { MMWR Morb Mortal Wkly Rep, } \\
1997\end{array}$ & $\begin{array}{l}9 \text { cases in Northern California required hospitalization after } \\
\text { eating Amanita phalloides }\end{array}$ & California \\
\hline O’Brien [8] & Am J Gastroenterol, 1996 & 4 cases of Amanita mushroom poisoning & Alabama \\
\hline Feinfeld [16] & J Toxicol Clin Toxicol, 1994 & $\begin{array}{l}4 \text { cases of poisoning with amatoxin-producing mushrooms in } \\
\text { suburban Long Island }\end{array}$ & New York \\
\hline Cappell [17] & J Clin Gastroenterol, 1992 & $\begin{array}{l}3 \text { residents developed gastrointestinal symptoms after } \\
\text { ingesting Amanita phalloides type mushroom }\end{array}$ & New Jersey \\
\hline Piering [18] & Clin Chem, 1990 & 2 cases of Amanita virosa mushroom poisoning & Wisconsin \\
\hline Pinson [22] & Am J Surg, 1990 & $\begin{array}{l}5 \text { cases of amatoxin poisoning, } 4 \text { of whom underwent liver } \\
\text { transplantation }\end{array}$ & Oregon \\
\hline Woodle [19] & JAMA, 1985 & $\begin{array}{l}\text { orthotopic liver transplantation in a 3-year-old girl with } \\
\text { acute hepatic failure secondary to Amanita poisoning }\end{array}$ & California \\
\hline Olson [20] & West J Med, 1982 & 10 cases of Amanita phalloides poisoning & $\begin{array}{l}\text { California } \\
\text { (San Francisco) }\end{array}$ \\
\hline Becker [21] & West J Med, 1976 & $\begin{array}{l}15 \text { cases of Amanita phalloides poisoning between } 1964 \text { and } \\
1974\end{array}$ & California \\
\hline
\end{tabular}




\begin{tabular}{r|l|l|l}
$\begin{array}{r}\text { Case Reports in } \\
\text { Gastroenterology }\end{array}$ & $\begin{array}{l}\text { Case Rep Gastroenterol 2012;6:350-357 } \\
\text { DOI: 10.1159/000339692 }\end{array}$ & $\begin{array}{l}\text { Published online: } \\
\text { June 7, 2012 }\end{array}$ & $\begin{array}{l}\text { @ 2012 S. Karger AG, Basel } \\
\text { ISSN 1662-0631 } \\
\text { www.karger.com/crg }\end{array}$ \\
\hline
\end{tabular}

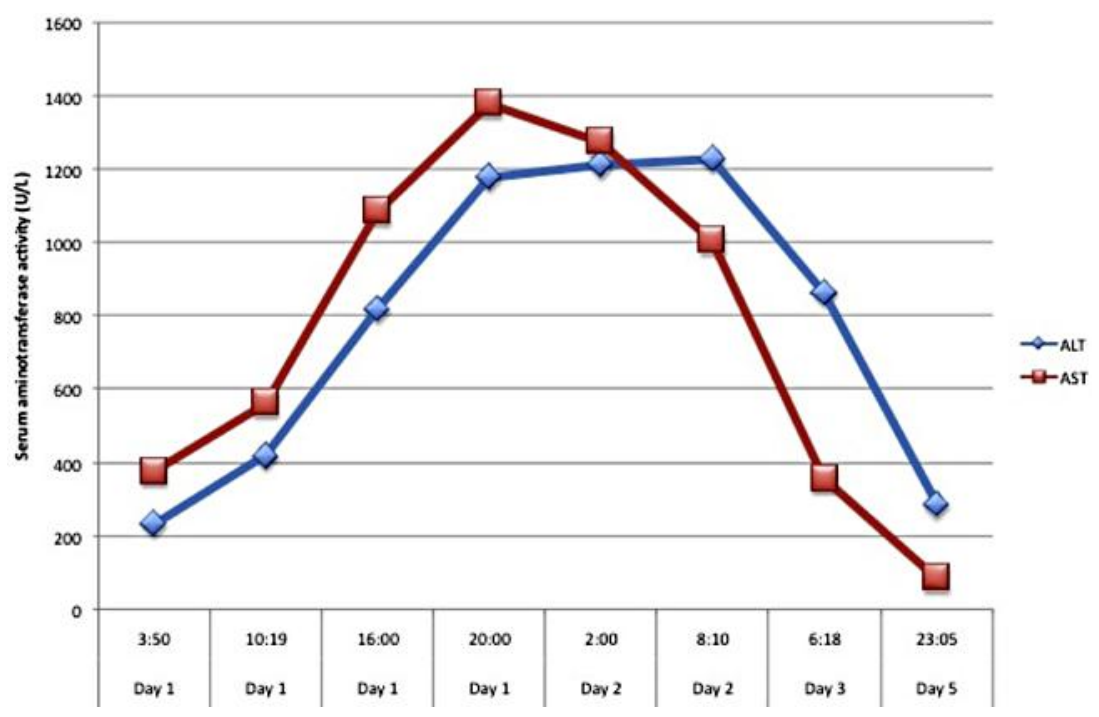

Fig. 1. Elevation of liver enzymes since admission to hospital indicating severe liver injury. 

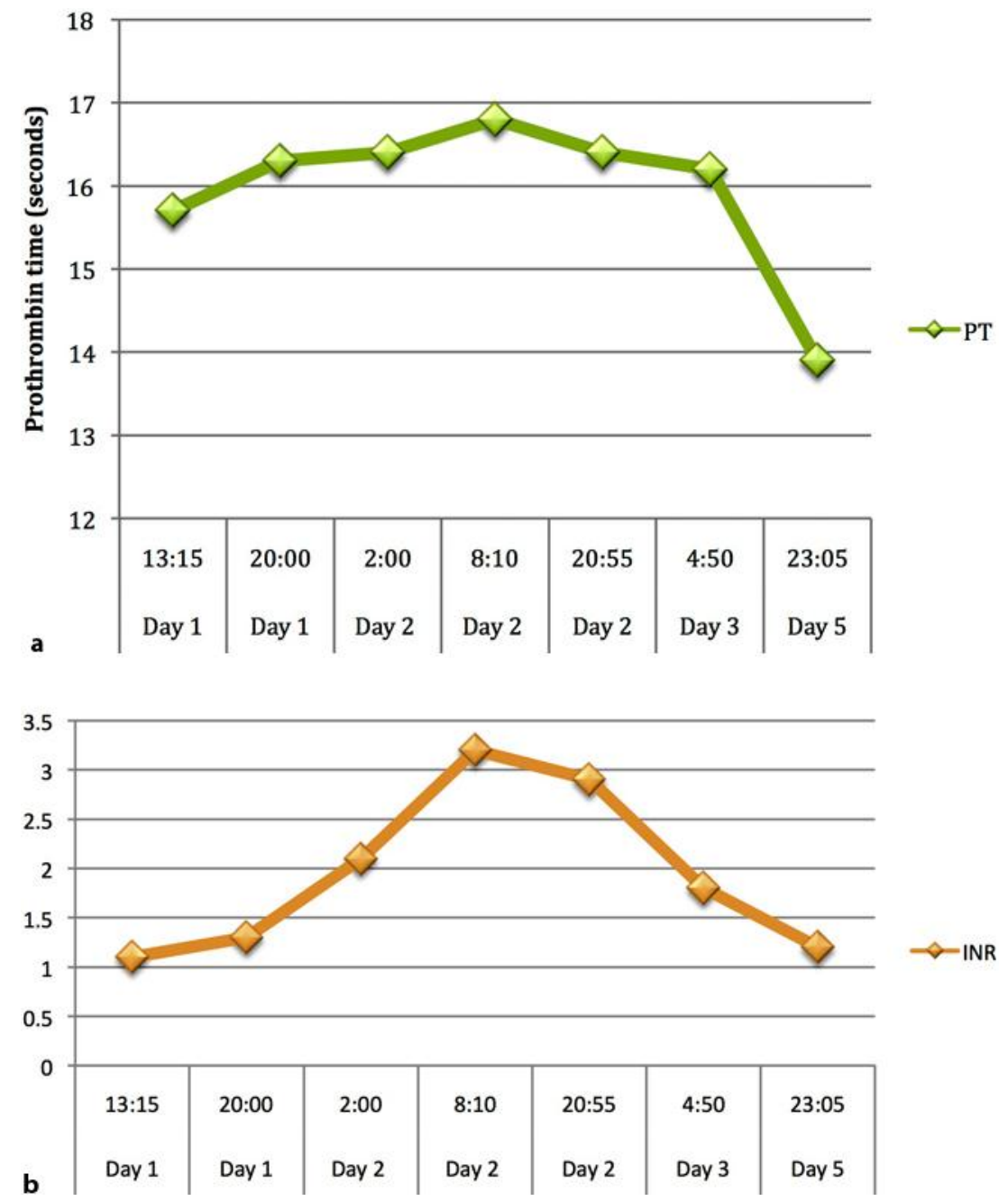

Fig. 2. Elevation of prothrombin time (a) and INR (b) indicating worsening of liver synthetic function throughout the hospital course.

\section{References}

-1 Broussard CN, Aggarwal A, Lacey SR, Post AB, Gramlich T, Henderson JM, Younossi ZM: Mushroom poisoning - from diarrhea to liver transplantation. Am J Gastroenterol 2001;96:3195-3198.

$\checkmark 2$ Cress CM, Malliah A, Herrine SK: Image of the month: fulminant hepatic failure caused by Amanita phalloides toxicity. Clin Gastroenterol Hepatol 2011;9:A26.

3 Barbee GA, Berry-Cabán CS, Barry JD, et al: Analysis of mushroom exposures in Texas requiring hospitalization, 2005-2006. J Med Toxicol 2009;5:59-62.

4 Karlson-Stiber C, Persson H: Cytotoxic fungi - an overview. Toxicon 2003;42:339-349.

5 Madhok M: Amanita bisporigera: ingestion and death from mistaken identity. Minn Med 2007;90:48-50.

-6 Madhok M, Scalzo AJ, Blume CM, Neuschwander-Tetri BA, Weber JA, Thompson MW: Amanita bisporigera ingestion: mistaken identity, dose-related toxicity, and improvement despite severe hepatotoxicity. Pediatr Emerg Care 2006;22:177-180.

-7 Warden CR, Benjamin DR: Acute renal failure associated with suspected Amanita smithiana mushroom ingestions: a case series. Acad Emerg Med 1998;5:808-812. 
8 0’Brien BL, Khuu L: A fatal Sunday brunch: Amanita mushroom poisoning in a Gulf Coast family. Am J Gastroenterol 1996;91:581-583.

-9 French LK, Hendrickson RG, Horowitz BZ: Amanita phalloides poisoning. Clin Toxicol 2011;49:128-129.

10 Enjalbert F, Rapior S, Nouguier-Soule, et al: Treatment of amatoxin poisoning: 20-year retrospective analysis. J Toxicol Clin Toxicol 2002;40:715-757.

11 West PL, Lindgren J, Horowitz BZ: Amanita smithiana mushroom ingestion: a case of delayed renal failure and literature review. J Med Toxicol 2009;5:32-38.

12 Pomerance HH, Barness EG, Kohli-Kumar M, Arnold SR, Steigelfest J: A 15 year old boy with fulminant hepatic failure. J Pediatr 2000;137:114-118.

13 Mullins ME, Horowitz BZ: The futility of hemoperfusion and hemodialysis in Amanita phalloides poisoning. Vet Hum Toxicol 2000;42:90-91.

14 Yamada EG, Mohle-Boetani J, Olson KR, Wener SB: Mushroom poisoning due to amatoxin: Northern California, winter 1996-1997. West J Med 1998;169:380-384.

15 Center for Disease Control and Prevention (CDC): Amanita phalloides mushroom poisoning - Northern California, January 1997. MMWR Morb Mortal Wkly Rep 1997;46:489-492.

16 Feinfeld DA, Mofenson HC, Caraccio T, Kee M: Poisoning by amatoxin-containing mushrooms in suburban New York - report of four cases. J Toxicol Clin Toxicol 1994;32:715-721.

17 Cappell MS, Hassan T: Gastrointestinal and hepatic effects of Amanita phalloides ingestion. J Clin Gastroenterol 1992;15:225-228.

18 Piering WF, Bratanow N: Role of the clinical laboratory in guiding treatment of Amanita virosa mushroom poisoning: report of two cases. Clin Chem 1990;36:571-574.

19 Woodle ES, Moody RR, Cox KL, Cannon RA, Ward RE: Orthotopic liver transplantation in a patient with Amanita poisoning. JAMA 1985;253:69-70.

20 Olson KR, Pond SM, Seward J, Becker CE: Amanita phalloides-type mushroom poisoning. West J Med 1982;137:282-289.

-21 Becker CE, Tong TG, Boerner U, et al: Diagnosis and treatment of Amanita phalloides-type mushroom poisoning: use of thioctic acid. West J Med 1976;125:100-109.

-22 Pinson CW, Daya MR, Benner KG, et al: Liver transplantation for severe Amanita phalloides mushroom poisoning. Am J Surg 1990;159:493-499. 